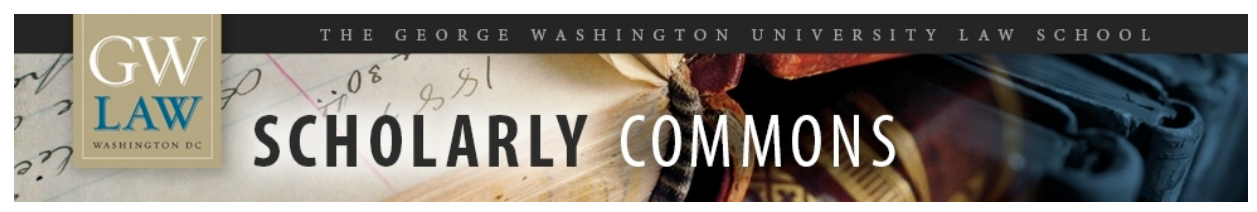

GW Law Faculty Publications \& Other Works

Faculty Scholarship

2015

\title{
The Puzzle of Alfarabi's Parallel Works
}

Miriam Galston

George Washington University Law School, mgalston@law.gwu.edu

Follow this and additional works at: https://scholarship.law.gwu.edu/faculty_publications

Part of the Law Commons

\section{Recommended Citation}

Galston, Miriam, The Puzzle of Alfarabi's Parallel Works (2015). 77 Review of Politics 519-543 (2015); GWU Law School Public Law Research Paper No. 2015-65; GWU Legal Studies Research Paper No. 2015-65. Available at SSRN: http://ssrn.com/abstract=2822482

This Article is brought to you for free and open access by the Faculty Scholarship at Scholarly Commons. It has been accepted for inclusion in GW Law Faculty Publications \& Other Works by an authorized administrator of Scholarly Commons. For more information, please contact spagel@law.gwu.edu. 


\title{
The Puzzle of Alfarabi's Parallel Works
}

\section{Miriam Galston}

\begin{abstract}
Scholars disagree about the correct interpretation of Alfarabi's Political Regime and Virtuous City, treatises that have striking similarities, yet notable differences. For some, the treatises encapsulate Alfarabi's philosophy; for others, they express only politically salutary opinions. Both interpretations fail to explain why he wrote parallel works. If both reflect Alfarabi's genuine philosophic doctrines, why did he compose separate but parallel treatises, both written when his philosophy was mature? Alternatively, if the treatises are political or rhetorical, why did Alfarabi compose two versions, and why did he choose these two accounts rather than others? To answer these questions, I discuss several overarching differences between the treatises, concluding that each work has an inner coherence and develops a distinctive narrative. I offer suggestions to account for the works' distinctive orientations, both to persuade doubtful readers of their philosophic significance and to suggest to both groups of scholars reasons for their systematic differences.
\end{abstract}

It is now widely recognized that medieval Islamic philosophy is Western philosophy in many, perhaps most, respects. Among other things, a large part of the writings of the preeminent medieval philosophers who wrote in Arabic consists in commentaries on the books of Plato, Aristotle, and their Greek and Neoplatonist successors, whose works were translated into Arabic starting in the eighth century AD. For example, Alfarabi, who is the subject of this study, wrote commentaries (sometimes in multiple versions) on all of Aristotle's logical writings, and he commented on Aristotle's Ethics, Rhetoric, Poetics, and Metaphysics as well as Plato's Laws. Like others in the Islamic philosophical tradition, Alfarabi also wrote independent treatises, that is, treatises on a variety of subjects that were not explicitly cast as reworkings of his Greek and Neoplatonist predecessors.

Alfarabi was the first philosopher writing in Arabic to write systematically in the area of political philosophy. His political works refer in varying degrees to traditional religious subjects, such as prophecy, prophets, revelation, the soul, and the next life. What is striking is the extent to which Alfarabi's treatment of these themes actually focuses on secular questions raised by Greek philosophers concerned about the relationship between philosophy and

Miriam Galston is Associate Professor of Law, The George Washington University, Law School, 2000 H St., N.W., Washington, DC 20052 (mgalston@law.gwu.edu). 
politics. For example, his discussions of revelation and prophecy clearly reflect Greek debates about such things as the origin of knowledge about human things, whether theoretical knowledge is necessary to ground political wisdom, and the role of moral virtue in enabling a political ruler to seek the good for his community. Even his discussions of the scope and character of political philosophy and political science reveal Alfarabi's conclusion that shari'ah had not superseded these disciplines or undermined their usefulness for understanding political life, including, it seems, the nature and role of shari’’ah itself.

In short, one can say that Alfarabi understands Islamic political philosophy as a subdivision of political philosophy more generally. As a consequence, nonspecialists who read Alfarabi will not only come to appreciate the degree to which he portrays the encounter between philosophy and revealed religion as mirroring the encounter between philosophy and political life in general. His political writings may also deepen their understanding of the tensions between the commitment to a philosophical life and engagement in politics, including the opportunities as well as the dilemmas these tensions occasion.

The present study examines two treatises that form part of Alfarabi's political writings: the Political Regime (PR) and the Virtuous City $(V C) .{ }^{1}$ It discusses problems of interpretation that arise because the content and structure of the two works are largely congruent, yet the works diverge, sometimes dramatically, in significant areas. I call this the "puzzle" of Alfarabi's parallel works. Although they do not approach it through the lens of a puzzle, scholars disagree about Alfarabi's purpose in writing the two works. For some, the two treatises are intended to encapsulate Alfarabi's mature theoretical and political philosophy. For Richard Walzer, for example, VC is Alfarabi's "last and most mature Summa Philosophiae." ${ }^{2}$ Other scholars, such as Deborah Black, Thérèse-Anne Druart, Majid Fakhry, Charles Genequand, and Damien Janos have similarly concluded that one or both treatises represent the mature philosophy of Alfarabi. ${ }^{3}$

\footnotetext{
${ }^{1}$ For bibliographic information, see notes 2 and 7-9 below.

${ }^{2} \mathrm{Abu}$ Nasr al-Fārābī, On the Perfect State (Mabādi' Ārā' Ahl al-Madīna al-Fādila), ed. Richard Walzer (Oxford: Clarendon, 1985), 1 (hereafter "Walzer, The Perfect State" for Walzer's comments and VC for Alfarabi's text).

${ }^{3}$ Deborah L. Black, "Al-Fārābī," in History of Islamic Philosophy, ed. Seyyed Hossein Nasr and Oliver Leaman (London: Routledge, 1996), 178, 188-90; Thérèse-Anne Druart, "Al-Farabi and Emanationism," in Studies in Medieval Philosophy, ed. John F. Wippel (Washington, DC: Catholic University Press, 1987), 22, 28, 38-42; Majid Fakhry, A Short History of Islamic Philosophy, Theology, and Mysticism (Oxford: Oneworld, 1997), 40; Charles Genequand, "Metaphysics," in History of Islamic Philosophy, ed. Nasr and Leaman, 783, 788-89; Damien Janos, Method, Structure, and Development in al-Fārābì's Cosmology (Leiden: Brill, 2012), 39-42, 179, 326ff. (hereafter al-Fārābī's Cosmology).
} 
A contrasting view has been developed by Leo Strauss and his students. Strauss asserted that views expressed in the cosmologies and sections on natural philosophy in the two works are actually "l'ensemble des 'opinions des gens de la cité parfaite'" and, therefore, their content is dictated by the needs of political life. ${ }^{4}$ Similarly, Muhsin Mahdi characterized the teachings of the treatises as "rhetorical" and "popular" and, thus, as "not embody [ing] either Alfarabi's theoretical philosophy or his practical philosophy." For these commentators, the treatises present models of the types of opinions about the world that a wise founder of a religion or political regime should communicate to the public to support the community and laws he establishes.

The positions of both groups of scholars fail to address the puzzle raised by the existence of contrasting versions of a seemingly unified project. As was noted by Amor Cherni, who edited and translated both works, the similarities and differences the two works exhibit create a need for exploring the relation between them. ${ }^{6}$ Dating the two treatises could facilitate this exploration; however, both books were apparently written in the last decade of Alfarabi's life, ${ }^{7}$ when his thought is unlikely to have changed significantly. Further, even if the dates of the treatises were established with certainty, it would still be necessary to determine whether different teachings in the later work were intended to supplant or, instead, merely to supplement the earlier work. This, in turn, presupposes understanding the conceptual relationship between the two treatises.

${ }^{4}$ Leo Strauss, "Quelques remarques sur la science politique de Maïmonide et de Fârâbî," Revue des Études Juives 100 (1936): 1, 5, 30-31.

${ }^{5}$ Muhsin S. Mahdi, Alfarabi and the Foundation of Islamic Political Philosophy (Chicago: University of Chicago Press, 2001), 3, 7, see 59, 123-24, 157 (hereafter Foundation). See Charles E. Butterworth, "Al-Fārābī's Introductory Sections to the Virtuous City," in Adaptations and Innovations: Studies in the Interaction between Jewish and Islamic Thought and Literature from the Early Middle Ages to the Late Twentieth Century, Dedicated to Professor Joel L. Kraemer, ed. Y. Tzvi Langermann and Josef Stern (Paris: Peeters, 2007), 27, 30 (hereafter "Introductory Sections") (much of what appears to be philosophic in the treatises "in no way represent[s] how al-Farabi actually views the universe and its parts"); Joshua Parens, Metaphysics as Rhetoric: Alfarabi's Summary of Plato's "Laws" (Albany: State University of New York Press, 1995), 20. See also Christopher A. Colmo, Breaking with Athens: Alfarabi as Founder (Lanham, MD: Lexington Books, 2005), 98-99; cf. 120-30.

${ }^{6}$ Abû Nasr al-Fârâbî, La politique civile ou les principes des existants, ed. and trans. Amor Cherni (Paris: Dar Albouraq, 2011), 15-16. See also Miriam Galston, Politics and Excellence: The Political Philosophy of Alfarabi (Princeton: Princeton University Press, 1990), chap. 5; Philippe Vallat, Farabi et l'école d'Alexandrie (Paris: J. Vrin, 2004).

${ }^{7}$ Al-Fārābī, The Political Regime (Al-Siyāsa al-Madaniyya, also known as the Treatise on the Principles of Beings), ed. Fauzi M. Najjar (Beirut: Imprimerie Catholique, 1964), 16-17 (Arabic). For Alfarabi's life, see Dmitri Gutas, "Fārābī. I. Biography," Encyclopaedia Iranica 9 (1999): 208-13; Janos, al-Fārābī's Cosmology, 12-16. 
The present study begins this inquiry by identifying several overarching differences between the works that, taken together, suggest that each work has an inner coherence and develops a distinctive narrative. Based upon the patterns identified, I offer suggestions for characterizing the orientation of each work. I hope, first, to persuade those who characterize the treatises as merely popular that they do reflect Alfarabi's philosophic views in important ways and, second, to prompt those who equate the two treatises with Alfarabi's mature philosophy to recognize the need to address the systematic differences the two works exhibit.

\section{Part of Natural Philosophy Is More Autonomous in the Political Regime than in the Virtuous City}

The treatises are known today in English as the Political Regime ${ }^{8}$ and the Virtuous City, ${ }^{9}$ although both English translations have generated some controversy. ${ }^{10}$ Both works can be roughly divided into two halves: the first describe subjects addressed by metaphysics or cosmology and natural philosophy, ${ }^{11}$ while the second halves treat overtly political themes.

\footnotetext{
${ }^{8}$ Citations are to Najjar's edition followed by citations to the English translation of Charles E. Butterworth in Alfarabi, The Political Writings, vol. 2, Political Regime and Summary of Plato's "Laws" (Ithaca, NY: Cornell University Press, 2015). An English translation of the first half by Jon McGinnis and David C. Reisman is in Classical Arabic Philosophy: An Anthology of Sources, ed. McGinnis and Reisman (Indianapolis: Hackett, 2007), 223-38 (hereafter Anthology). For English translations of the second half, see Fauzi M. Najjar, in Medieval Political Philosophy: A Sourcebook, ed. Ralph Lerner and Muhsin Mahdi (Ithaca, NY: Cornell University Press, 1963), 32-56 (hereafter Sourcebook); Charles E. Butterworth, in Medieval Political Philosophy: A Sourcebook, ed. Joshua Parens and Joseph C. Macfarland (Ithaca, NY: Cornell University Press, 2011), 37-55 (hereafter Sourcebook2). English translations are my own unless otherwise noted.

${ }^{9}$ Citations are to Walzer's edition, above note 2 , followed by that of F. Dieterici (Leiden: Brill, 1895/1964).

${ }^{10}$ See Dmitri Gutas, "The Meaning of Madanī in al-Fārābī's 'Political Philosophy,'” Mélanges de l'Université Saint-Joseph [hereafter MUSJ] 57 (2004): 259, 260-69, and Amor Cherni, La politique civile, 11-13 (both reject translating madan̄ as "political"). Compare Charles Genequand, "Loi morale, loi politique: al-Fārābī et Ibn Bağğa," MUSJ 61 (2008): 491, 499-503. I use "Political Regime" because it is used widely and in Najjar's edition. See also Gutas, review of Alfarabi and the Foundation of Islamic Political Philosophy, by Muhsin S. Mahdi, International Journal of Middle East Studies 35 (2003): 146 (rejecting "Virtuous City" because the full Arabic title focuses on the principles of the citizens' opinions).

${ }^{11}$ The systematic treatment of politics in $P R$ begins midway through the work $(P R$ 69:16). $V C$ is not divisible into "halves" so neatly, since some topics covered by $P R$ in the political half occur in the portion of $V C$ prior to the explicitly political part.
} 
The first halves depict the universe as a series of concentric spheres containing cosmic intelligences and heavenly bodies that ultimately derive from a first cause. ${ }^{12}$ The cosmologies in the treatises are very similar in many respects and identical in some. Thus, at first glance, the parallel cosmologies appear to convey roughly the same narrative about the origin and structure of the universe. Nonetheless, the two accounts contain certain discrepancies that, in aggregate, indicate that part of natural science plays a more prominent and autonomous role in $P R$ than in $V C$. This difference, in turn, has implications for the works' respective discussions of political life.

First, $V C$ opens with a lengthy elaboration of the "first being," which is the first cause of the existence of all other beings. ${ }^{13}$ In contrast, the first sentence of $P R$ refers to "the principles by which bodies and their accidents are constituted." ${ }^{14}$ Elsewhere Alfarabi defines natural science as the science that gives an account of "the principles of the natural bodies and the principles of their accidents." ${ }^{15}$ The first sentence of $P R$ thus evokes the perspective of natural science, rather than metaphysics, as does the beginning of $V C$.

Second, the first half of $V C$ follows an emanationist ${ }^{16}$ organization that depicts the universe as descending from the first being, through the heavenly intellects and planets, and ending with the moon (VC 112:13-114:4/22:6-12). The last intellect in the chain, later identified as the agent intellect, is thus ten levels removed from the first cause. ${ }^{17}$ In contrast, the first page of $P R$ states that the first cause is the proximate cause of the existence of the heavenly intellects and also of the existence of the agent intellect (PR 31:12-13/29:19-21). $P R$ departs, then, from the linear emanationist structure of $V C$ by making the agent intellect independent of the other heavenly intellects (called "the seconds"). ${ }^{18}$ Because the agent intellect is also associated with the sublunar

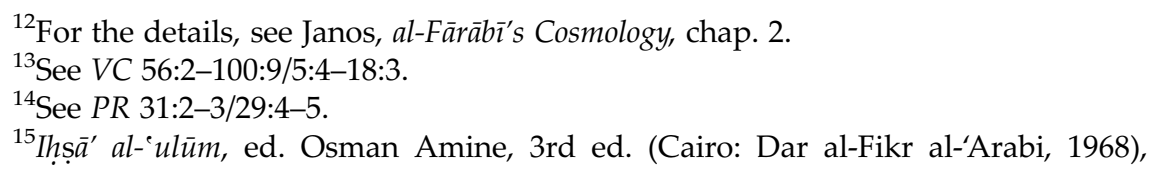
116:12-13 (hereafter Enumeration); see 11:4-6. English translation by Charles E. Butterworth is in Alfarabi, The Political Writings, vol. 1, Selected Aphorisms and Other Texts (Ithaca, NY: Cornell University Press, 2001), 71-84 (hereafter Political Writings I).

${ }^{16}$ On this term, see Lloyd P. Gerson, "Plotinus's Metaphysics: Emanation or Creation?," Review of Metaphysics 46 (1993): 559-74.

${ }^{17}$ See VC 104:3-11/19:22-20:4, 114:1-2/22:9-10. The agent intellect is not mentioned by name until the end of the first half of VC (202:7-9/45:9-10).

${ }^{18}$ The suggestion of independence is reinforced when $P R$ refers repeatedly to "the second [intellects] and the agent intellect" (emphasis added) in places for which the counterpart passages in VC refer to "the second [intellects]" in aggregate, without distinguishing the agent intellect. Compare $P R$ 49:1-52:5/44:1-46:13 with VC 100:11-104:11/19:1-20:4. See also PR 31:4/29:7-8 (assigning the second intellects to the second rank and the agent intellect to the third rank), 31:7-8/29:11-13, 34:16/ 32:21-22, 40:1/37:3; VC 104:6-11/19:23-20:5; Janos, al-Fāräbī's Cosmology, 143-44, 174-76. 
sphere in both treatises, the effect of attributing its existence directly to the first cause in $P R$ is to suggest a degree of autonomy for the part of the natural world associated with the agent intellect. To that extent, natural science would be independent of cosmology. ${ }^{19}$

Third, after the paragraph stating the direct causal relation between the first cause and the agent intellect, $P R$ contains several pages outlining the different types of soul, focused primarily on the agent intellect's functions, including its role enabling people to actualize their potential as rational beings (see $P R$ 32:6-34:15/30:2-32:20). This creates another contrast: the movement in $V C$ is from the supralunar cosmos to the sublunar world, whereas $P R$ begins discussing an important part of the sublunar or natural world and only afterward elaborates the first cause, heavens, and sublunar world in the traditional order. $^{20}$ Part of natural science, namely, philosophical psychology, ${ }^{21}$ thus seems independent of part of metaphysics or the study of the heavens.

In sum, because of the differences in the structure and topics of the initial sections of the two treatises, $P R$ appears to portray part of the natural world and natural science, namely, human rationality and philosophical psychology, as more autonomous than they appear in $V C$.

\section{The Life of the Mind as a Way of Life Is Pivotal to the Political Regime, but Not to the Virtuous City}

In both treatises, human perfection is portrayed in terms of a human being (or his intellect) transcending, i.e., not needing, his (or its) material attributes to "subsist" or "be constituted" (fi qiwāmih). ${ }^{22}$ Transcendence does not require the literal death of the body: in both treatises, the first ruler who has attained revelation achieves transcendence, yet subsequently engages in a variety of helpful political activities while still very much alive. ${ }^{23}$ Transcendence may

${ }^{19}$ Of course, the sublunar world remains influenced by the supralunar world in other ways.

${ }^{20}$ Contrast Druart, "Al-Farabi and Emanationism," 38-42, who characterizes $P R$ 31-42/29-39 as "a brief study of each of the principles he has just listed," and PR $42-69 / 39-60$ as "an account of how all beings derive from the first cause."

${ }^{21}$ For the view that the study of the soul belongs to natural science, at least insofar as it is connected with body, see Aristotle, On the Soul 403a27-28; Black, "Al-Fārābī," 189.

${ }^{22}$ Qiwām may refer to a thing's physical existence or survival. See VC 228:2-3/53:8-9. Elsewhere it refers to something fundamental, like a thing's core or self. See Alfarabi, Al-Fārāäì's Philosophy of Aristotle (Falsafat Aristūuttālìs), ed. Muhsin Mahdi (Beirut: Dār Majallat Shi'r, 1961), 89:16-17 (in his exploration of natural beings, Aristotle connects each being's "what-ness," "substance," qiwām, and "nature"). See also Alfarabi, Eisagoge (Kitāb Isāghūjī Ay al-Madkhal), in Al-Manțiq 'inda al-Fārābī, ed. Rafìq al-'Ajam, vol. 1 (Beirut: Dar al-Mashriq, 1985), 87:3; English in Anthology, 55.

${ }^{23}$ See, e.g., $P R$ 79:3-17/68:28-69:2, 83:12-13/72:31-34; VC 242:15-246:7/58:13-59:13. See also Muhsin Mahdi, Abū Nașr Al-Fārābī, Kitāb al-Milla wa Nuṣuṣ UkhrālAlfarabi's 
occur when a human engages in the spiritual or intellectual activity that is essential to his identity ${ }^{24}$ without requiring material support or bodily involvement for its exercise. Examples might be attaining a level or type of cognitive inquiry in which the mind ceases to rely on sense data ${ }^{25}$ or contemplating objects or activities that themselves have no material existence, for example, thinking about the nature of the soul, the mind, or thought itself. Perhaps transcendence refers to thinking about things that do have a material existence, but at a level of abstraction or generality such as occurs in parts of logic, mathematics, physics, or metaphysics. Transcendence could then refer to reflection on the nature of causation, relation, magnitude, etc., without reference to the attributes of any particular object of which these notions can be predicated.

1. Three models of the role of the agent intellect in developing reason. Whatever the precise content of the activity of the soul that attains transcendence, both treatises portray the agent intellect as partly responsible for a person's ability to achieve it. Several places in $P R$ suggest that the agent intellect actively and directly makes certain things happen to human beings or to the rational faculty by using the Arabic causative form to describe its actions. For example, the agent intellect seeks to "cause [the rational animal] to obtain [tabligh]" the highest levels of perfection (PR 32:6-7/30:3-4) and "it causes [the rational faculty] to become [yușayyiru]" actual intellect (PR 35:6/38:1-2).

Elsewhere in $P R$, Alfarabi explains the action of the agent intellect by employing the light image used by Aristotle in On the Soul. ${ }^{26}$ In these passages, the agent intellect is said to supply the human mind with something akin to light in the domain of sense perception, which enables sight to perceive the material world (PR 35:12-17/33:12-21). Hence, a person "becomes" actual intellect "through this" (bihi yașirru) (PR 36:1-2/33:24-25), with the agent intellect a catalyst or indirect cause of the transformation of potential intellect into actual intellect.

A third approach to the relation between the agent intellect and the human mind is captured in a passage that describes the agent intellect as providing humans perfection beyond bodily perfection by giving man "a faculty [quwwah] and a principle [mabda'] with which he strives, or with which he

Book of Religion and Related Texts (Beirut: Dar al-Mashriq, 1968), 45:7-9 (hereafter Religion) (connecting misery, but not happiness, with the next life). An English translation is in Butterworth, Political Writings I, 93-113. Butterworth has "the next life" modify both happiness and death (ibid., 95).

${ }^{24}$ See $P R$ 35:4-5/32:37-38 (the rational faculty is what a makes a human being a human being).

${ }^{25}$ See Alfarabi, Fușūl Muntaza'ah (Selected Aphorisms), ed. Fauzi M. Najjar (Beirut: Dar el-Mashriq, 1971), No. 81, 86:10-87:7; English in Butterworth, Political Writings I, 11-67.

${ }^{26}$ Aristotle, On the Soul $3.5430 \mathrm{a} 14-17$. 
has the capacity to strive, on his own for the remaining perfections" (PR 71:14-16/62:19-22). ${ }^{27}$ This suggests that transcendence requires a greater degree of initiative on a person's part than is evoked by the first two approaches because the agent intellect imparts only a faculty and a principle, because these are said to enable a human being to strive or "to have the capacity" to strive, and because Alfarabi adds the qualification "on his own" (PR 71:15-16/62:22). In the same vein, Alfarabi observes that once people obtain the primary cognitions afforded by the agent intellect, they are capable of choice and thus the ability to strive "or not to strive" for happiness (PR 72:9-14/63:3-11). Perfection and happiness are thus doubly contingent because they depend in part on the agent intellect and in part on human striving, but the agent intellect can only make possible, not assure, the existence of striving. $^{28}$

The counterpart passages in $V C$ contain many elements of the first two models of the agent intellect's function present in $P R .^{29}$ The treatises differ, however, as regards the third model. Although $V C$ contains the doctrine that transcendence cannot occur without certain acts of the human will (VC 204:15-206:4/46:10-11), it also states that contemplation and other forms of reasoning arise "naturally" once primary intelligibles emerge in the human mind (VC 204:6-8/45:22-23). Further, it fails to mention the possibility that people will not choose to use the intelligibles to engage in the pursuit of further knowledge or that the pursuit will entail striving. It also lacks a discussion like the one in $P R$ regarding the wide variation in people's capacities for grasping primary intelligibles beyond those apprehended by almost all people (PR 75:5-17/65:17-37). In fact, according to $V C$, the emergence of primary intelligibles will naturally trigger a desire for further discovery (VC 204:6-7/45:22-23). One consequence of these features of VC is that the development of human reason appears less problematic than it does in $P R$. By the same token, the emphasis on individual initiative in $P R$ suggests that cognitive development depends upon a person's voluntary efforts over time. This, in turn, implies a commitment or way of life devoted in significant part to taking advantage of the initial endowment associated with the agent intellect.

2. Education and instruction. In $P R$, Alfarabi says that most people have sound innate human dispositions and grasp intelligbles "common to all"; this enables them to strive after matters and activities they have in common (PR 75:4-5/65:14-16). Beyond these common things, people are said to possess varying abilities for grasping intelligibles. Some can grasp intelligibles only in certain subjects; some are limited in the number of intelligibles

${ }^{27}$ Philippe Vallat, al-Fārābī: Le livre du régime politique (Paris: Belles Lettres, 2012), 132-33, equates the faculty with the principle.

${ }^{28}$ People's capacity for perfection also depends upon their natural endowments, which are traceable, in part, to their material circumstances; these, in turn, reflect the positions and motions of the heavenly bodies. See PR 70:8-71:13/61:11-62:16.

${ }^{29}$ See VC 198:4-15/44:1-9, 200:1-202:16/44:11-45:15. 
they can grasp within a subject; and they have varying abilities to use intelligibles to derive further discoveries (istinbāt ) (PR 75:5-17/65:17-37). Finally, this passage notes that two people who are equally adept in all of the above respects may nonetheless differ in their capacity to teach $\left(t^{\prime} \mathrm{l} l \bar{m}\right)$ and guide (irshād) others about what they have themselves discovered (PR 75:17-76:1/65:37-66:3). There is no parallel in $V C$ for the types of comparisons between people described in this paragraph.

This extended passage in $P R$ thus introduces the theme of the importance of education and training for developing human reason. In the following pages, Alfarabi cautions that naturally having an innate disposition for something only makes it easier to do what one is naturally disposed to do and to be motivated to do if no external force exerts pressure in the opposite direction (PR 76:3-6/66:5-10). As a consequence, he says that, to reach their final perfections, all people, regardless of the innate dispositions they possesses naturally, need to be trained and educated in the things toward which they are disposed (PR 76:11-13/66:17-20). Otherwise even people with very superior innate dispositions may lose the benefit of their original endowments ( $P R$ 76:13-14/ 66:20-23), and people with lesser natures who are educated in a particular field can actually surpass in accomplishments those with superior natures that lack such education (PR 77:12-14/67:16-19).

The narrative of $P R$ thus shifts from the contributions to the human project made by the heavenly bodies and the agent intellect to the contributions required by individuals and to the danger of squandering people's natural aptitudes, if proper nurturing does not take place. ${ }^{30}$ One theme of the passage summarized is thus the importance of the transmission of learning, or the tools that make learning possible, within a community and from generation to generation.

These themes are also not repeated in $V C$. That treatise does state that people possess varying abilities in "the arts and the like" (VC 238:14-240:1/ 57:6-9, see 266:6-268:2/65:15-66:5), but does not elaborate people's differences respecting the sciences, intelligibles, reasoning from intelligibles, and guiding or teaching others. ${ }^{31} \mathrm{VC}$ also states that people have varied innate endowments (fitar), but it does so only in the context of their participation as citizens of a city (VC 232:5-234:5/54:19-55:11). Thus, ruling and being ruled are presented in political terms in $V C$, whereas $P R$ depicts hierarchies of ruling and serving in both political and cognitive terms. This contrast is consistent with one treatise depicting the agent intellect as a catalyst for human effort and the other stating that reasoning arises naturally when certain conditions exist. Thus, the emphasis on education and instruction in $P R$ supports the identification of human perfection with a rational life understood as an ongoing endeavor.

\footnotetext{
${ }^{30}$ Alfarabi uses forms of three terms in the passage summarized: $t a{ }^{\prime} a d d u b$, irshād, and ta'tim. Although in general $t a^{\prime} a d d u b$ can mean breeding or moral education, in this context, it seems that Alfarabi has in mind rational development.

${ }^{31} \mathrm{VC}$ does, of course, speak to these qualities in a founder or ruler.
} 
3. Contrasting treatments of man's bodily existence. The above differences between the two works appear connected to a striking difference in the attention they pay to man's bodily functions. $V C$ contains lengthy and detailed discussions of the parts of the body (e.g., limbs, nerves, organs) and the intricacies of human reproduction (VC 174:10-196:3/37:12-43:8). PR does not even allude to these topics.

Relatedly, when VC outlines the five faculties of the human soul (VC 164:215/34:13-35:1), it elaborates in detail how the nutritive faculty works with various organs (VC 166:1-12/35:1-10). In contrast, nutrition is not mentioned in $P R$, even when Alfarabi enumerates the faculties of the human soul (PR 32:14-33:15/30:17-31:21, see 73:10-11/63:35-37). ${ }^{32}$ Consequently, the human soul has only four faculties in $P R$, whereas in $V C$, it has five. ${ }^{33} V C$ implicitly explains $P R$ 's omission when it states that the nutritive faculty exists only to serve the body, whereas the remaining faculties exist to serve both the body and reason (VC 206:16-208:1/46:21-47:1). PR thus ignores the aspect of the soul that has no direct effect on the rational faculty.

In $V C$, the concept of "rule" (riyassah) is introduced in the context of bodily or material substances (VC 162:4/34:4-5) and then developed through descriptions of the workings of the faculty of nutrition, bodily organs, and sense perception (VC 166:1ff./35:1ff., 196:7-8/43:10-12). In PR, in contrast, "rule" is introduced in connection with the mind, specifically, in the passage detailing the differing abilities that people have for discovery and guiding others in cognitive pursuits (PR 77:7-17/67:8-28, see 78:8-16/68:10-22). Since the concept of rule, or governance, is the organizing principle of large parts of both works, the context in which Alfarabi first chooses to emphasize that hierarchies imply rulership is noteworthy. In $V C$, it is empirical observation about the way competing limbs and organs work together in a harmonious whole that triggers the idea of rank ordering and governance. In $P R$, the rank ordering of cognitive capacities and accomplishments triggers the idea that some individuals are fit to rule over others in certain respects.

The contrasts discussed so far can be connected as follows. $P R$ emphasizes the centrality of reason in the world more than $V C$ by attributing the existence of the agent intellect directly to the first cause; discussing the agent intellect, the rational soul, and intellectual perfection in the opening pages of the book; and minimizing its recognition of the material component of human life. ${ }^{34}$

${ }^{32}$ They are the rational, appetitive, imaginative, and sense-perceptive faculties.

${ }^{33} P R$ 73:10-11/63:35-37 says that there are five faculties of the human soul: the theoretical rational, the practical rational, the appetitive, the imaginative, and the sense-perceptive. Thus, in this passage there are five faculties because the rational is subdivided into theoretical and practical faculties.

${ }^{34} P R$ does, however, acknowledge the role of appetite in the genesis of volition (PR 72:5-7/62:30-35) and implies that appetite determines whether someone who grasps the nature of happiness through theoretical inquiry will make its pursuit his life's mission (see PR 73:13-18/64:4-12, 74:5-12/64:20-29). 
Correspondingly, $V C$ takes the material dimension of humanity more seriously than $P R$ by detailing the nature of the heavenly bodies (the source of the material stratum of life on earth) prior to describing man's rational potential, elaborating the operation of man's bodily systems in great detail, and associating rulership with the material and political strata of existence. ${ }^{35}$

Consistent with framing the contrasts this way is $V C^{\prime}$ s focus on how each faculty comes into being (hadatha). ${ }^{36}$ The account of the soul in $P R$, in contrast, is presented as a classification of the faculties based upon the function or character of each. ${ }^{37}$ The former account thus focuses on the "what" and the "from what" of each faculty, whereas the latter views the soul in terms of the "what" and the "for what." ${ }^{38}$ The account of the soul in $V C$ thus emphasizes the agent and material causes, whereas $P R$ highlights the formal and final causes. ${ }^{39}$ Similarly, since the agent intellect's function is portrayed as "seeking to enable [or cause] the rational animal to reach its highest degree of perfection, namely, ultimate happiness" (PR 32:6-7/30:3-4), and perfection is characterized in several places in terms of a relation with the agent intellect (PR35:4-11/32:3733:11, 35:17-36:5/33:22-30, 71:10-13/52:13-16), PR introduces the notion of ends as causes in the beginning of the treatise, with its initial description of the agent intellect.

$P R^{\prime}$ s initial focus on final causes does not on its own necessitate the thesis of this section about rational development as a way of life, but it is suggestive because the agent and material causes are oriented toward what happens to humans viewed as recipients, whereas final causes are oriented toward the ends pursued (and not necessarily attained). ${ }^{40}$ In sum, stepping back from the technical details of the two works, it is noteworthy that PR's focus on education and certain facets of cognitive development has no counterpart in $V C$ and that $V C^{\prime}$ 's preoccupation with bodily functions has no counterpart in $P R$. This difference is epitomized by the fact that the soul in $P R$ has four faculties, whereas in $V C$, it has five because nutrition is considered part of the soul. Because cognition is elaborated in $P R$ in terms of human striving and because of the book's orientation toward ends and ultimate ends, the

\footnotetext{
${ }^{35}$ See also VC 178:9-16/38:15-19 (describing how bodily functions and states affect the capacity for thinking).

${ }^{36}$ VC 164:2-15/34:13-35:1. Similarly, the Summary of VC references the genesis of the objects of discussion repeatedly in the first half of the work. See VC 38-48/1-4.

${ }^{37}$ Likewise $P R$ initiates a discussion of several topics with a theoretical or conceptual map that situates the subject to be discussed in a larger framework. See, e.g., $P R$ 31:211/29:4-17, 58:1-3/51:9-12, 69:5-17/60:1-22, 77:1-17/66:27-67:28.

${ }^{38}$ See PR 36:15-16/34:11-13; Alfarabi, Tahsīl al-Sa'ādah, ed. Ja'fir al-Yasin (Beirut: Al-Andaloss, 1981), 52:10-17 (hereafter Happiness), translated in Sourcebook and Sourcebook2.

${ }^{39}$ See $P R$ 42:13/39:9-10 (the rational part of the human soul is itself a cause in the sense of an end and not in the sense of an agent).

${ }^{40}$ See subsection 3 of the next section, below.
} 
development of reason in that work appears to entail commitment to cultivating and sustaining a way of life that minimizes the importance of bodily needs to the greatest extent possible.

\section{Politically Salutary Opinions Matter More to the Virtuous City than to the Political Regime}

$P R$ was often transmitted with the subtitle The Principles of the Beings. ${ }^{41}$ The full title of $V C$ is The Principles of the Opinions of the Inhabitants of the Virtuous City. To understand the contrast suggested between the principles of the beings and the principles of the citizens' opinions requires examining Alfarabi's understanding of the nature of opinion and the role opinions play in a political community.

1. Opinions and imagery. According to both treatises, all citizens of virtuous cities ought to know about the ultimate principles and ranks of the beings, happiness, the first rulership of a virtuous city, and the ranks of rule in that city. ${ }^{42}$ Alfarabi sometimes calls such beliefs about fundamentals, combined with practical precepts concerning how people should behave, the religion (millah) or law (shari' ah) of a community. ${ }^{43}$ Both treatises observe that these topics can be known either by means of some kind of rational cognition or through a person's imagination (PR 85:3-4/74:8-10, see VC 278:8-10/69:19-21). In the former case, the essential natures of the things can be known "as they really are"; in the latter, a person "knows" imaginings, images, or imitations of things, rather than things as they really are. ${ }^{44}$ According to $P R$, "most people" can only know fundamentals through images, not as they really are (PR 85:12-14/74:24-28, 86:28/75:3-13; see Religion 47:22). Most people should therefore be taught these things using images ( $P R$ 85:12-14/74:24-28). Both works recognize that, to be persuasive, images must be cast in terms familiar to the intended audience and that what is familiar varies from group to group or nation to nation (PR 86:4-5/75:6-9; VC 280:1-4/70:6-7). Thus, both

\footnotetext{
${ }^{41}$ According to Najjar, Political Regime, 11-12 (Arabic), the first mention in Arabic sources of $P R$ being known as The Principles of Being occurs in Ibn Abī Ușaibi'ah,

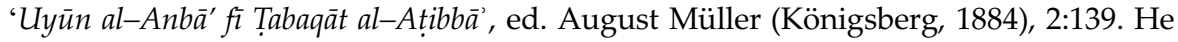
died three centuries after Alfarabi's death. As Najjar notes, the Jewish philosopher Moses Maimonides used that title almost a century earlier. See "Letter from Maimonides to Samuel ibn Tibbon," in Letters of Maimonides, ed. Isaac Shailat (Jerusalem: Maliyot, 1988), 530, 553 (medieval Hebrew text of the letter).

${ }^{42}$ See PR 84:17-18/74:1-4; cf. 85:3-4/74:8-10. The list has more detail and a different emphasis in VC 276:10-278:5/69:6-17.

${ }^{43}$ See Alfarabi, Religion 46:11-14; PR 85:18-86:2/75:1-3.

${ }^{44}$ See PR 85:3-6/74:8-13; VC 278:8-11/69:19-70:1. In Religion (46:17-18), Alfarabi also observes that the opinions of the "virtuous religion" can be the truth (al-haqq) or an image of the truth (mithāl al-haqq).
} 
works envision multiple virtuous nations and cities, each with a religion employing distinctive imagery to describe what citizens should believe, even if they pursue the same understanding of happiness (PR 85:17-86:1/74:34-75:3; VC 280:4-6/70:6-10).

Alfarabi's insistence on the necessity for rulers to ensure that citizens' opinions are convincing and held in common derives from his view that people's opinions about the world, man's place in it, and nature in general are likely to influence their character, moral norms, and behavior. ${ }^{45} P R$ captures this concern when it discusses potential images that a ruler could select along three dimensions: first, whether they are better or worse imaginative representations; ${ }^{46}$ second, their proximity or distance from the truth about the world; and third, the quantity, visibility, and persuasive power of the "points of contention" the images chosen elicit. ${ }^{47}$ The work cautions that, if it is necessary to choose among these criteria, proximity to the truth is of less importance than the quality of an imaginative representation and avoiding numerous or obvious points of contention (see PR 87:2-4/75:33-36). ${ }^{48}$ This statement is surprising if one thinks that the assertion "religion is an imitation of philosophy" ${ }^{\prime 9}$ implies that fidelity to underlying philosophic truths should be the dominant standard for evaluating religious imagery.

$P R$ does not explain the reason for not ranking the truth content of imagery as the highest criterion, leaving the impression that the purpose of citizens having beliefs about fundamentals derives more from their political salience than their intellectual content. $V C$ develops this impression by elaborating at length the potential damage if people recognize the problematic aspects of doctrines portrayed through images (VC 280:7-14/70:11-18). For example, some may assume that the beliefs taught contain no truth at all and, thus, become skeptical about the possibility of truth simply; others may take advantage of questions provoked by imagery to repudiate the beliefs taught

\footnotetext{
${ }^{45}$ See Religion 45:20-24; see also 43:3-44:6; Aphorisms, No. 61; VC 286-328/72-85 (how ignorant opinions influence conduct).

${ }^{46}$ The text says, "Some are more judicious [ahkam] and complete [atamm] imaginings, while others are more defective" (PR 86:11-12/75:18-19). Najjar translates ahkam "better" (Sourcebook, 41); Butterworth translates "wiser" (Sourcebook2, 43). Arabic $h^{*} k^{*} m$ can refer to wisdom or judgment.

${ }^{47}$ PR 86:11-14/75:18-23; see VC 280:11-13/70:14-16. "Points of contention" is Najjar's translation (Sourcebook, 41). Walzer (281) translates "grounds for objection."

${ }^{48}$ Cf. Happiness 91:11.

${ }^{49}$ As Joshua Parens notes, Alfarabi attributes this potentially heretical proposition to "the Ancients" (Parens, An Islamic Philosophy of Virtuous Religions: Introducing Alfarabi [Albany: State University of New York Press, 2006], 97; see Alfarabi, Happiness 90:1415). Alfarabi seems to elaborate the doctrine in his own name in Religion 46:22-47:16; Alfarabi's Book of Letters (Kitāb Al-Hurūf): Commentary on Aristotle's Metaphysics, ed. Muhsin Mahdi (Beirut: Dar el-Mashriq, 2004), 131, I108.
} 
and justify indulging in a life devoted to "ignorant goods," such as honor, wealth, or physical pleasures, rather than real goods. ${ }^{50}$ In short, if religious imagery is open to frequent objections that lead to such things as skepticism or hedonism, it will be ineffective or even dangerous.

Further, according to $V C$, people who observe that the world appears to be in constant flux may conclude that nothing can be known with certainty and permanence (VC 286:3-8/72:1-2). People who observe that many parts of nature are antagonistic to each other may conclude that there is no order or criterion of desert in nature (VC 286:9-290:4/72:2-73:1). They may then reason that political life should mirror nature: cities should fight and seek to subdue other cities, and individuals should view one another as enemies and only cooperate out of necessity (see VC 290:5-292:5/73:2-16). Such people would then endorse the precept that "might makes right" and conclude that justice consists in dominating others through force and rewarding the best warriors (see VC 292:6-296:12/73:17-74:23, 298:4-300:10/75:8-76:6).

$V C$ cautions further that, to those who generalize these notions, laws for fair dealing in commercial transactions, norms of good behavior, and even religious teachings linking certain types of conduct to reward and punishment in the next life could all be seen as strategies adopted by weak people to compensate for their inability to obtain what they want through force. ${ }^{51}$ According to such people, "the good consists in ruling by force, to be attained in two ways, by straight attack and by deceit: whoever is capable of straightforward attack will act accordingly and who is not, will succeed by cheating, fraud and treachery, ruse, hypocrisy, deceit and leading people astray" (VC 314:7-10/80:12-14, trans. Walzer).

In sum, that proximity to the truth is not the dominant criterion for evaluating imagery, as is stated in $P R$ and implied in $V C$, is a consequence of the social, ethical, and political impact that citizens' beliefs about the world may have on their behavior as individuals and as members of a community.

2. Citizen opinions and the city's well-being. The preceding raises the following conundrum. Citizens must hold certain beliefs about fundamentals, but most people can only grasp them through images, not as they really are. What, then, is the status of the doctrines advanced in the two treatises, which include fundamentals such as the citizens should grasp?

The emanationist cosmologies in $V C$ and $P R$ depict a universe of order, permanence, essential natures, and causal relations; everything occupies a place in one or more clearly delineated hierarchy. The entire universe unfolds, as it were, from a single, simple, unifying causal principle. ${ }^{52}$ Thus, although

${ }^{50}$ See VC 282:6-284:12/71:1-21. In some cases, imagery that triggers controversy can have a beneficial effect. See VC 280:15-282:5/70:18-71:1; PR 104:17-105:6/91:13-25.

${ }^{51}$ See generally VC 300:11-308:7/76:7-78:14. This brief summary does not do justice to the richness of the description in these passages.

${ }^{52}$ See PR 57:1-3/50:16-19 (the first cause is the cause of both necessary being, which must exist, and possible being, which can exist or not); VC 94:7-8/17:2-3 (same). 
emanationist cosmologies may originate in theoretical insights, they also describe the origin or structure of the universe in a manner consistent with the practical needs of individuals and communities. People who accept the cosmologies literally are unlikely to view the world as fundamentally arbitrary or chaotic. Theory and the demands of practical life thus appear to coincide.

The sublunar world, in contrast, poses a greater challenge because it is characterized by contingency and contrariety. Both treatises seem to address the threats this poses by emphasizing the permanence within nature and by using political terminology to describe the natural world. ${ }^{53}$ For example, $P R$ states that it is the nature of possible beings to be capable of existing or ceasing to exist, or to exist in a definite way although an opposing being will also exist, because possible beings are made up of matter and form. It is the nature of matter to be able to exist in contrary ways, and this is matter's due (haqq) and merit (istihāl), while it is in the nature of form to exist as it is without ceasing to exist, and this is its due and merit. Generation and corruption are then expressly portrayed as expressions of "justice" in nature. ${ }^{54}$

The effect of framing the transformation and decay that natural bodies undergo in terms of desert and justice is to impose a kind of orderliness and fittingness in what might otherwise appear to be random and unsettling. These passages may be part of what impelled the commentators mentioned earlier to believe that the two treatises are merely rhetorical and popular, rather than philosophical. Alfarabi's purpose in casting natural phenomena in terms of justice and merit, in other words, could be signaling that apparently theoretical portions of the treatises are really driven by the need to establish salutary opinions for citizens rather than by his philosophic insights.

This is not the only plausible inference, however, even if Alfarabi did characterize the workings of nature as "just" for rhetorical reasons. As is argued below, the presence of distinctive narratives in the two treatises tends to undermine the view that the works are devoid of philosophical content. Moreover, $P R$ contains numerous important teachings that do not seem salutary for the "multitude." Finally, because the discrepancies between the two works are consistent with the contrasts developed in sections I and II above, there appear to be philosophic reasons for Alfarabi's decision to create parallel depictions of the universe and mankind's place in it.

\footnotetext{
${ }^{53}$ See Abû Nasr al-Fârâbî, Opinions des habitants de la cité vertueuse, ed. Amor Cherni (Paris: Dar Albouraq, 2011), 124n2, 126n2.

${ }^{54}$ This is a brief summary of $P R$ 56:13-62:10/50:7-54:28. The counterpart passage in $V C$ (144:3-162:13/30:6-34:11) also emphasizes that the existence of contrariety and generation and corruption derive from the natures of matter and form, describes the changes that occur as what they merit, and uses "justice" to describe the changes dictated by their natures.
} 
3. The Political Regime contains views likely to unsettle citizens. In several areas, the content of $P R$ seems potentially more controversial than the counterpart narrative of $V C$. Several aspects of the portrayal of the agent intellect fall under this heading. First, according to $P R$, the agent intellect represents providence (or concern, 'ināyah) with respect to human beings ( $P R$ 32:6), but this is what it seeks (iltimās) (PR 32:6-9/30:2-5), ${ }^{55}$ not necessarily what it achieves. In the second half of the work, Alfarabi underscores the limitations of providence by stating that the heavenly bodies are indifferent to the agent intellect's activities and, accordingly, at times operate in ways that obstruct its purpose (PR 73:1-8/63:20-32).

It is difficult to understand why Alfarabi would include this potentially disturbing picture of a world in which matter and motion can obstruct the force for reason and human perfection, given $P R$ 's concern about avoiding points of contention in imagery used to teach people about the world. ${ }^{56}$ By the same token, it is not surprising that the passage about the heavens and agent intellect working at cross purposes is not repeated in $V C$. $V C$ also presents a less problematic world by omitting $P R$ 's depiction of the agent intellect as dependent upon human striving to fulfill its function.

A similar discrepancy exists in the treatises' portrayals of the workings of nature. Although both cast contingency and contrariety in terms of nature's "justice," VC characterizes the degree of justice exhibited in nature far more extravagantly: in $V C$, the citizens should know $^{57}$ that everything that happens to any of the possible beings reflects "precision, perfection, providence, justice, and wisdom" (VC 276:10-278:1/69:613). In PR, in contrast, justice inheres in things' natures rather than in every happening they experience.

The contrast between the treatises can also be seen in their descriptions of revelation. In both, revelation consists in an emanation to the human mind attributable to the agent intellect and the first cause. ${ }^{58} P R$ says that the emanation occurs from the agent intellect to the human mind and then adds that "it may be possible to say that the first cause is the source of revelation to this human being through the mediation of the agent intellect because the agent intellect emanates from the existence of the first cause" (PR 80:1-3/ 69:20-23). This sentence is startling because it appears to limit the agency of

${ }^{55}$ On different meanings of 'ināyah see Alfarabi, Aphorisms, No. 87. See also Walzer, The Perfect State, 473-74.

${ }^{56} V C$ (142:8-13/29:20-23) also notes that heavenly bodies may assist or oppose the sublunar beings. However, this general statement is not connected to the activity of the agent intellect and does not draw out the implications for the possibility of human perfection, as occurs in $P R$. The counterpart general statement is at $P R$ 64:13-14/56:19-20.

${ }^{57}$ Reading ya'lamahā with Dieterici (69:6) and Cherni (281:4), rather than ya'malahā with Walzer (276:10).

${ }^{58}$ See PR 79:12-80:3/69:9-23; VC 244:1-16/58:15-59:4. 
the first cause in revelation to the mere fact that its existence is the source of the agent intellect's existence, instead of portraying the first cause as actively involved in the process and content of revelation.

According to $V C$, revelation occurs when the agent intellect acts on both the theoretical and practical parts of a human being's rational faculty as well as his imaginative faculty (VC 244:7-9/58:18-20). Alfarabi then adds that "Allah, powerful and sublime, reveals to him through the mediation of the agent intellect, so that what emanates from Allah, blessed and exalted, to the agent intellect is what emanates from the agent intellect" to the person's intellect and imagination (VC 244:9-12/58:20-22). ${ }^{59}$ The deity is thus identified as the source of the content of revelation, whereas the agent intellect serves merely as an intermediary. ${ }^{60}$

These differences in the description of revelation are consistent with the suggestion that $P R$ accords the agent intellect and philosophical psychology a degree of autonomy that is lacking in VC. In the same vein, $P R$ asserts that revelation, i.e., the union of the human and agent intellects, is explained in On the Soul (PR 79:9-11/69:4-8), ${ }^{61}$ reinforcing the impression that revelation can be understood completely without recourse to theology or religion. This impression is also consistent with Alfarabi's statement elsewhere that how revelation occurs became clear in theoretical science. ${ }^{62}$

$P R$ contains additional teachings that could well be controversial to ordinary citizens. Both treatises include "the first rulership" among the fundamentals that the inhabitants of the virtuous city should know about (PR 84:17-18/74:1-3; see VC 278:3/69:15). For both, the first ruler is a person who has achieved theoretical and practical rational perfection and who can figure out and prescribe for others the means to attain happiness. ${ }^{63}$ Both works ascribe revelation to the first ruler (PR 79:12-80:3/69:9-24; VC 244:313/58:15-23). ${ }^{64}$ And both contemplate the possibility of multiple "first"

\footnotetext{
${ }^{59}$ The quotation ends "to his passive intellect through the mediation of the acquired intellect; then to his faculty of imagination" (VC 244:12-13/58:22-23). See Herbert A. Davidson, Alfarabi, Avicenna, and Averroes on Intellect: Their Cosmologies, Theories of the Active Intellect, and Theories of Human Intellect (Oxford: Oxford University Press, 1992), 9-12. The role of imagination in revelation in VC has been discussed extensively. See Fazlur Rahman, Prophecy in Islam: Philosophy and Orthodoxy (London: George Allen \& Unwin, 1958), 30-91.

${ }^{60}$ Noteworthy, of course, is that VC references "Allah." However, the contrast is not between a natural as against a theological account of revelation. Despite the religious terminology, the portrayal of revelation in $V C$ depicts natural processes, i.e., the interaction between the rational and imaginative faculties of the human soul.

${ }^{61}$ Both Aristotle and Alexander of Aphrodisias wrote a book with this title. See Cherni, La politique civile, 160n395.

${ }^{62}$ Religion 44:12-13.

${ }^{63}$ See PR 79:3-80:5/68:28-69:27; VC 240:1-248:14/57:9-60:11.

${ }^{64}$ See also Religion 44:6-13.
} 
rulers, i.e., a series of individuals all of whom attain the level of perfection attained by the initial first ruler explicitly depicted as receiving revelation (PR 80:14-15/70:10-14; VC 248:15-250:6/60:11-15).

Only $P R$, however, contains the following observation:

Just as it is permissible for each of them to change a Law that he had legislated at one time... for another if he deems it better to do so [at another time], similarly it is permissible for the living who succeeds the one who died to change what the latter had legislated, for the one who died also would have changed it had he been able to observe the new conditions. (PR 80:15-81:2/70:14-20, trans. Najjar)

This passage in $P R$ is surprising because it legitimates alterations of revealed law (sharī'ah) based upon changing circumstances, ${ }^{65}$ which seems to cast doubt upon the understanding of revealed law ${ }^{66}$ as conveying permanent truths that can be added to but not supplanted. It is difficult to understand why Alfarabi would incorporate the doctrine of the superiority of living wisdom in $P R$ so openly after the advent of Islam if his goal was driven primarily by rhetorical or popular considerations. ${ }^{67}$ Among other reasons, although Islamic doctrine acknowledges the validity of successive prophets before Mohammed, when prophecies were all directed to a specific time and place, Mohammed's prophecy is said to surpass all earlier prophecies and his teaching is considered final. ${ }^{68}$ Thus, it is perplexing that $P R$ mentions the ability of successive first rulers to replace elements of revealed law. ${ }^{69}$

\footnotetext{
${ }^{65}$ Religion (49:9-14) is more forceful: it is the obligation of a first ruler who follows another first ruler "to alter much of what the [original] first had legislated and to determine it in another way, when he knows that this is best for his time-not because the first one erred, but because the first one made a determination according to what was best for his time and this one makes a determination according to what is best subsequent to the time of the first, this being the kind of thing the first would alter also, were he to observe it" (trans. Butterworth).

${ }^{66}$ That the first ruler, who establishes rules for a community (millah), does so based upon knowledge obtained through revelation is stated in Religion 44:6-7 and is implied in PR 79:3-80:3/68:28-69:24.

${ }^{67}$ For competing views about the role of Islam in Alfarabi's thought, see Alexander Wain, "A Critical Study of Mabādi' ārā' ahl al-madinna al-fādila: The Role of Islam in the Philosophy of Abū Nașr," Journal of Islamic Philosophy 8 (2012): 45; Philippe Vallat, "al-Fārābī's Arguments for the Eternity of the World and the Contingency of Natural Phenomena," in Interpreting the Bible and Aristotle in Late Antiquity, ed. Josef Lössl and John W. Watt (Farnham: Ashgate, 2011), 259.

${ }^{68}$ This analysis is based upon Qur'an 33:40. See Brannon M. Wheeler, Prophets in the Quran: An Introduction to the Quran and Exegesis (New York: Continuum, 2002), 332-33. Figh applies and extends the Prophet's teachings; it does not replace them.

${ }^{69} \mathrm{PR}$ famously never mentions prophets or prophecy, whereas VC explains in detail how prophecy occurs.
} 
Although VC also describes successive rulers of virtuous cities (VC 250:6252:10/60:15-61:11), it fails to say that either they or the initial first ruler could alter revealed law owing to changing circumstances.

The problematic character of the quoted passage is compounded when Alfarabi adds that, should there be a break in the succession of perfect rulers, the law at the time of the last such ruler should be codified and written down (PR 81:2-3/70:20-23). Since the reader was just informed that even laws determined as a result of revelation may need to be altered with changing circumstances, it seems that, over time, permanent written laws risk becoming less than optimal after their codification, despite their revealed origin. This inference is not obvious in the passage in $V C$ stating the need to codify laws if the succession of first rulers is broken (VC 250:4-6/60:15-17), because this work lacks the additional claim that first rulers may need to alter shari'‘ $a$ h with changing circumstances. Thus, $V C$ avoids alluding to the most disturbing feature of codified, unalterable law. $P R$, in contrast, offers a potentially provocative account of written law based upon revelation, which is at odds with the work's own advice to avoid doctrines unsettling to citizens at large.

4. Implications for the traditional interpretations of the treatises. The preceding contrasts make it difficult to maintain that the treatises are simply summaries of Alfarabi's mature philosophy, since they appear to reflect two distinct philosophic perspectives. Some method or approach seems necessary to determine which orientation more truly represents Alfarabi's philosophy or how his mature philosophy somehow encompasses both. ${ }^{70}$

Scholars who instead see the treatises as primarily political or rhetorical have endorsed some version of the view that the works are intended only as "templates" of regimes for "future founders or lawmakers" to imitate or legislate. ${ }^{71}$ If so, and the statements about the cosmos and mankind are rhetorical because most people can understand only images and the images are chosen for their political utility, then why does $P R$ contain the potentially controversial doctrines discussed above? Also, why would Alfarabi imagine that people who can only grasp images could nonetheless accept doctrines, like those in $V C$ and $P R$, that are so obscure they have challenged students of Alfarabi for centuries? ${ }^{72}$

If the point is rather that Alfarabi intended the treatises to influence and be used by political leaders, not the public at large, ${ }^{73}$ the treatises' doctrines would presumably still be conveyed in a simplified version by founders to nonphilosophers and nonrulers. If so, why compose two versions of the template, and which leaders should build upon which template? To understand

\footnotetext{
${ }^{70}$ See below, section IV.

${ }^{71}$ Mahdi, Foundation, 6-7, 123-24, 156-57.

${ }^{72}$ See Strauss, "Quelques remarques," 5 (the treatises' views on metaphysics and natural philosophy are actually the opinions of citizens of the perfect city).

${ }^{73}$ See Mahdi, Foundation, 157.
} 
which template to use, the leaders would have to figure out the purpose(s) underlying the differing templates. ${ }^{74}$ At that point, the works would cease to be simply popular; they would compel inquiry into the significance of portraying the universe and the place of mankind in distinct ways. The need to choose between the templates would thus seem to trigger and give direction to philosophic investigation.

Muhsin Mahdi refers once to the possibility that the treatises may also be "used by students of philosophy to understand their own political-theological predicament." ${ }^{\prime 75}$ Although this suggestion, standing alone, might concede that the treatises have genuine philosophic content, the sentence is followed by Mahdi's assertion that the treatises do not embody Alfarabi's philosophytheoretical or practical. ${ }^{76}$ It is difficult to understand how works that do not embody Alfarabi's philosophy would nonetheless be useful to students of philosophy seeking insight into their political-theological predicament, which is itself a subject of political philosophy.

In contrast to Mahdi and Butterworth, Ulrich Rudolph argues that the structure of the treatises resembles the structure of the literature known as ușull al-dīn, or principles of faith. ${ }^{77}$ This might make the two treatises a species of theology, recalling the suggestion of Butterworth and Parens that the treatises are examples of Alfarabi's own kaläm, or theology. ${ }^{78}$ The treatises would, then, be examples of the kalām of a philosopher wearing a theologian's hat rather than legislation for the members of a religious or political community. This possibility is attractive since kalām frequently employed technical arguments and complicated notions to defend more basic religious teachings. ${ }^{79}$

${ }^{74}$ Contrast Butterworth, "Introductory Sections," 38, who says that in the first part of $V C$, "without invoking any kind of religious doctrine, [Alfarabi] has shown what is sound in the religious narrative with which we are familiar. His account has also suggested how these matters might be depicted in a manner friendly to revealed religion yet without calling on the tenets of any particular creed." Butterworth does not address the issues raised by the existence of two narratives. In addition, the two works do far more than identify aspects of conventional religion that are "sound." The works also seem too abstract to guide leaders to citizen-friendly religious teachings.

${ }^{75}$ Mahdi, Foundation, 6-7. Mahdi seems to have borrowed this expression from Strauss. See Leo Strauss, Spinoza's Critique of Religion, trans. E. M. Sinclair (Chicago: University of Chicago Press, 1997), 1.

${ }^{76}$ Mahdi, Foundation, 7.

${ }^{77}$ Ulrich Rudolph, "Reflections on al-Fārābī's Mabādi' ārā' ahl al-madīna al-fādila," in In the Age of al-Farabi: Arabic Philosophy in the Fourth/Tenth Century, ed. Peter Adamson (London-Turin: The Warburg Institute, 2008), 1, 6-13 (hereafter "Reflections").

${ }^{78}$ See Butterworth, "Introductory Sections," 42; Parens, Metaphysics as Rhetoric, 19-20, 139-41.

${ }^{79}$ For Alfarabi's overview of the methods of some theologians, see Enumeration 132:8-138:5. 
It raises other questions, however. For example, if the purpose of theology is to defend "the specific opinions and actions that the founder of the religion declared and to refute by arguments whatever opposes it" (Enumeration 131:10 12, trans. Butterworth), what religion(s) are the treatises defending and what opponents is Alfarabi trying to refute? Why are there two treatises ostensibly devoted to the same project? Are there two different religions to defend? And why include ideas in either book that could unsettle the virtuous citizens?

According to Rudolph, although $V C$ is "intended to deal comprehensively with themes and challenges taken from systematic theology," it is not itself a work of theology. ${ }^{80}$ Since the title of $V C$ begins with the word "principles," rather than "opinions," its content "meet[s] the standards of philosophy." 81 On the face of it, Rudolph and Mahdi-Butterworth adopt incompatible views. Whether that incompatibility would survive scrutiny depends upon the extent to which Alfarabi's philosophical theology is not only occasioned by, but itself reflects, the author's mature philosophy. ${ }^{82}$

\section{Conclusion}

If one assumes that the treatises reflect Alfarabi's mature philosophy, why did he compose more than one such treatise?

The titles suggest one distinction. $P R$ was known as The Principles of the Beings, and the work's stated theme is the principles by which the corporeal entities that make up the world are constituted (PR 31:2-11/29:4-5). In contrast, the theme of $V C$ is the principles of opinions that the virtuous city's inhabitants should hold. Both works express the view that the opinions of most people about fundamentals are likely to reflect images rather than philosophic truths. The titles thus suggest a contrast between principles explaining the sensible world as it really is and principles of beliefs for conveying to virtuous citizens at large, to the extent that these differ. So understood, The Principles of the Beings might seem more philosophic in purpose or content than the counterpart treatise.

That $P R$ is somehow more philosophic is also suggested by the fact that only $V C$ considers imagination a form of knowledge (VC 36:14-15) ${ }^{83}$ and it

${ }^{80}$ Rudolph, "Reflections," 14. Cf. Massimo Campanini, "Alfarabi and the Foundation of Political Theology in Islam," in Islam, the State, and Political Authority, ed. Asma Afsaruddin (New York: Palgrave Macmillan, 2011), 35.

${ }^{81}$ Rudolph, "Reflections," 3.

${ }^{82}$ Whether or how works of philosophic theology, such as Maimonides's Guide of the Perplexed, represent an author's philosophy is a question beyond the scope of this article.

${ }^{83} \mathrm{VC}$ accords a higher status to imagination than does $P R$ in other ways. The most obvious example is that imagination is central to the former work's discussion of prophecy. Compare VC 240:10-246/57:13-59:9 with PR 79:3-80:4/68:28-69:25. 
alone describes beliefs adopted on the authority of trusted wise people as knowledge of things "as they are" (VC 278:10-12/69:22-70:1). ${ }^{84}$ The philosophic orientation of $P R$ prevents it from similarly elevating the status of such opinions. ${ }^{85}$ The book's philosophical orientation is also suggested by its procedure, when it begins a new subject, of introducing a conceptual framework situating the subject in a larger context or classification. The philosophical orientation further explains why $P R$ devotes extensive attention to abstract topics like the nature of possible being (PR 56-62/50-54, 64-68/55-59) - subjects that are treated summarily in $V C$.

The titles suggest another difference between the treatises. One work adopts the political regime as its framing concept, whereas a framing concept of the other is the virtuous city. "Regime" is more generic than "city" and could include rules governing other kinds of association or even a private individual's way of life. ${ }^{86}$ "Regime" could thus include what today would be called a "virtual city" in addition to one with bricks and mortar. $P R$ thus accommodates ordering ways of life to happiness in a manner more generic, hence flexible, than is signaled by the title of $V C{ }^{87}$

These differences suggested by the titles are related. Among the range of governances contemplated by $P R$ is that of individuals attracted to a philosophic life. This is clear from that work's sustained treatment of people's varying capacities to grasp and reason from intelligibles, their rank in guiding others, and their need to be trained, educated, and instructed regardless of the level of their natural capacities. ${ }^{88}$ The emphasis on the city in $V C$, with its connotation of an association of people residing within a geographical locus and sharing a common goal, helps explain the relative absence of these subjects in that work (see VC 228:11-228:8/53:17-54:7). The interpretation advanced here is similarly helpful for understanding why the concept of "rule" is introduced in $P R$ in the passage about people's cognitive development, whereas it is introduced in VC in connection with man's bodily functions.

\footnotetext{
${ }^{84}$ For a fuller account of this notion, see Happiness 90:3-91:12 (describing what is "called popular, generally-accepted, and external philosophy" [trans. Mahdi]). Butterworth translates words from the root " ${ }^{*}{ }^{*} f$ as forms of "cognizance" rather than "knowledge," so that the reader can recognize distinctions Alfarabi makes between the two terms.

${ }^{85}$ See also PR 73:9-18/63:37-64:12 (happiness can be known only through theoretical reason and only on that basis can the good subject to human control be known).

${ }^{86}$ See Patricia Crone, "Al-Fārābī's Imperfect Constitutions," MUSJ 57 (2004): 191. PR (80:7-9/69:30-70:3) contemplates the possibility of individual people subject to the "rule" of a first ruler without, however, living in one place or at one time. The word siyāsah, in the title, does not appear in the body of the work. For Alfarabi's understanding of the term, see Enumeration 125:10-11; Religion 54:14-15; Aphorisms, Nos. 88-91.

${ }^{87}$ See Parens, Metaphysics as Rhetoric, 166n1.

${ }^{88}$ Compare VC 238-240/57 (a hierarchy of political arts).
} 
No wonder, then, that the only qualifications listed in $P R$ for being a first ruler are cognitive and pedagogic achievements ( $P R$ 79:3-80:3/68:28-69:25). In contrast, according to $V C$, a first ruler must also have a "tough physique, in order to shoulder the tasks of war" and have "limbs and organs which are free from deficiency and strong... to make him fit for the actions which depend upon them" (VC 246:4-5/59:8-9, 246:9-10/59:14-15, trans. Walzer). ${ }^{89}$ Including the first ruler's need to conduct wars and be physically fit is consistent with the thesis that $V C$ emphasizes a veritable over a virtual city.

This interpretation also explains why $V C$ says that to attain his preservation and perfection, every person needs the association of many groups who cooperate to provide their respective needs, whereas the counterpart passage in $P R$ maintains that humans belong to the species that cannot obtain necessities nor its most excellent states without many groups associating in one location. ${ }^{90}$ The latter formulation leaves open the possibility that not all members of the species need political association equally. Presumably all humans need others to obtain necessities and a level of comfort sufficient to pursue their private objectives. It is nonetheless not surprising that $P R$ 's silence about nutrition and bodily functions and its preoccupation with the life of the mind would lead it to abbreviate its account of these needs.

The interpretation developed here also explains the statement in $P R$ that the democratic city is "the most admirable and happy" of the ignorant cities (PR 100:11/87:11, trans. Najjar), ${ }^{91}$ despite the fact that the timocratic city, not democracy, resembles the virtuous city $\left(P R\right.$ 93:13/81:13) ${ }^{92}$ and is the best of the ignorant cities (PR 94:1-2/81:17). ${ }^{93}$ The democratic city protects the freedom of all the inhabitants to do what they want; and this, in turn, makes possible the emergence of all human types, the best and the worst (see PR 100:12-101:5/87:13-30). Democracy is thus the regime most compatible with cultivating a variety of private purposes.

The contrast between the principles of beings and the principles of citizens' opinions also goes hand in hand with the willingness of $P R$ to include cosmological doctrines and political precepts that could prove politically destabilizing in preference to more conventional doctrines, if that is where inquiry

\footnotetext{
${ }^{89}$ For Alfarabi's understanding of war in his commentary on Plato's Laws, see Parens, Metaphysics as Rhetoric, 69-75.

${ }^{90}$ Compare PR 69:16-17/60:20-22 with VC 228:2-8/53:8-15. The passage in VC says "every one" or "every person" three times. See also Galston, Politics and Excellence, 150n13.

${ }^{91}$ Butterworth translates "This is the marvelous and happy city."

${ }^{92}$ Alfarabi adds that this is "especially [the case] if honors and people's rankings in honors are because of what is most useful for others-whether wealth, pleasure, or other useful things a seeker desires" (PR 93:13-94:1/81:13-17).

${ }^{93}$ On this potential contradiction, see Mohammad Ali Khalidi, "Al-Fārābī on the Democratic City," British Journal for the History of Philosophy 11 (2003): 379-94 (concluding that Alfarabi favored democracy over timocracy).
} 
leads. That a concrete polity with a primary focus on the collective good would be more concerned with promoting opinions that avoid controversy than one committed to creating an environment in which individuals are free to question authority in the pursuit of knowledge is also consistent with the view being developed here.

The thesis that $P R$ develops a view of political life that privileges the pursuit by individuals of knowledge as a way of life may also be the reason for the stark dichotomy drawn in that book between the rule of the first ruler, who achieves revelation, and all other rulers (PR 80:12-81:4/70:8$24)$. The cultivation of an intellectual elite would seem to presuppose thoughtful, often individualized and personal instruction by someone thoroughly grounded in the philosophic enterprise. In contrast, the possibility of a multiplicity of types of rulers of cities of excellence, as are enumerated in $V C$ (250:6-252:10/60:15-61:11), may be appropriate for the needs of a political community in which communal goods are the foremost goal. By the same token, the viability of multiple virtuous rulerships makes the political project of $V C$ more feasible than that of $P R$. This may explain why the discussion of nonvirtuous regimes is much lengthier in $P R$ than in $V C{ }^{94}$

The above interpretation does not imply that all the views in $P R$ reflect philosophic truths, as Alfarabi understands them, whereas the views in $V C$ (insofar as they differ) are merely rhetorical or for popular consumption. Nor does it imply that $P R$ points toward philosophic insights without regard to their political impact. It is more accurate to say that the accounts in $P R$ emphasize considerations important for encouraging some individuals to pursue science and philosophy in a manner not inconsistent with the goal of communal political well-being, whereas the counterpart accounts in $V C$ take their bearings by communal well-being in ways not inconsistent with the possibility of individual pursuits without obvious utility for the polity. Although this difference could be cast as one of degree, in light of the numerous differences highlighted in this essay, it is more accurate to see it as a difference in kind.

$V C$ would thus be a philosophic book, one that outlines the human situation if the primary goal is facilitating the well-being of polities in a concrete setting. In that event, a prophet's or other leader's ability to communicate using images comprehensible to the citizenry at large would be more critical than in $P R$, where prophecy is never mentioned and the highest authority is living wisdom subject to ongoing revision. In $V C$, the city is necessary for the wellbeing of every individual, and the first ruler is presented as the means to achieve that end. So understood, the first ruler's art is subordinate to the

\footnotetext{
${ }^{94}$ In other words, $P R$ seems to be pointing out the fragility of the human project understood in terms of cultivating conditions for the life of the mind (e.g., the work's observations about the variation among human aptitudes, the impediments caused by the material properties of human beings and nature as a whole, and the necessity of theoretical knowledge for the possibility of perfection or happiness).
} 
city's purpose, in contrast to $P R$, where the first ruler appears to be what he is even if his followers do not constitute a concrete city. The first ruler of $P R$ needs revelation, but not necessarily prophecy, which presupposes a highly developed imagination and faculty for imitation, since the first ruler of the $P R$ governs individuals in the first instance and only governs cities if he gets lucky.

The preceding reflections indicate the need to reopen the question of whether, or to what extent, the two treatises convey aspects of Alfarabi's philosophic teachings. Those who take the position that the treatises are distillations of Alfarabi's mature philosophy should, in this author's opinion, engage to a greater degree with the puzzle posed by the existence of two such distillations and the seeming inner coherence of each before treating the contents of the treatises as interchangeable or complementary. By the same token, those who view the treatises as not reflecting Alfarabi's philosophy might also revisit their assumptions in light of some of this essay's findings. That one treatise suggests philosophical psychology can be understood as independent of metaphysics, for example, would seem to derive from theoretical inquiry; it recalls Alfarabi's suggestion in the Attainment of Happiness that the investigator explores human rationality and celestial metaphysics independently of one another. ${ }^{95}$ In addition, the treatises' distinctive accounts of the types of rulership necessary to found and govern a virtuous city may reflect Alfarabi's understanding of the relative merits of those who govern with the wisdom of a philosopher as compared with those who rule with the wisdom of a statesman. This interpretation would then coincide with distinctions made in the Book of Religion and Enumeration of the Sciences between the concept of political science that is connected to theoretical philosophy and the concept of political science that is not. These examples could be multiplied, and they all point to the likelihood that the two treatises elaborate distinctive notions of the discipline of political philosophy or science, the foundations presupposed by each, and the types of political or human communities each is peculiarly suited to foster.

The preceding analysis does not completely resolve the puzzle of why Alfarabi wrote two treatises and why these two treatises. It contributes to the solution by identifying some of the most significant differences between the treatises' respective narratives and sketching in broad strokes the possible philosophic and communal objectives underlying the distinctive narratives. For the present, both the existence of the differences highlighted in this essay and the arguable coherence of the patterns they suggest caution against relegating the two treatises to the status of mere popular and rhetorical undertakings at the same time that they create obstacles to presuming, without further inquiry, that the two treatises exemplify a single philosophy.

\footnotetext{
${ }^{95}$ See Alfarabi, Philosophy of Plato and Aristotle, rev. ed. Muhsin Mahdi (Ithaca: Cornell University Press, 1969), xv-xvii; Galston, Politics and Excellence, 192-99.
} 